\title{
Economic viability of the mechanized harvesting system in financial cash of a sugarcane (Saccharum spp.) mill
}

\section{Viabilidade econômica do sistema de colheita mecanizado em caixa financeiro de usina de cana-de-açúcar (Saccharum spp.)}

\author{
Neisvaldo Barbosa dos SANTOS ${ }^{1}$; Roberto Soares do NASCIMENTO²
}

${ }^{1}$ Autor para correspondência, Mestre em Máquinas Agrícolas, Prof. Adjunto I de Mecânica e Mecanização Agrícola, da Universidade Federal do Piauí - UFPI, Campus Professora Cinobelina Elvas, Rodovia Municipal Bom Jesus - Viana, Km 01, Planalto Horizonte, CEP 64.900-000, Bom Jesus, PI; neisvaldo@gmail.com

${ }^{2}$ Especialista em Gestão do Agronegócio, Teresina,PI; roberto_agropr@hotmail.com

Recebido em: 01-03-2021; Aceito em: 26-05-2021

\begin{abstract}
Brazil is the world's largest producer of sugarcane for sugar, alcohol, and bioenergy mills. These mills have been taking into account production costs in order to facilitate financial control, assist in the decision-making process to profit from agricultural activity, and to be more competitive in the market. The mills invest in the acquisition of harvesters and tractor-trailer combinations to enable the cutting, harvesting, and internal loading of sugarcane. However, the acquisition of the mechanized harvesting system machines requires a high investment on the projected cash flow of the mill. Therefore, this study aims to identify the economic viability of a mechanized sugarcane harvesting system for the financial cash of the mill. The methodology considers the costs of implantation and cultivation of the crop of projected future seasons, cost analysis using the net present value and the internal rate of return, and reference mechanisms such as the benefit-cost ratio, discounted payback, and break-even point. This methodology was used to compose the financial cash of the mill, which also included the use of secondary data. In order to generate data for the mechanized sugarcane harvesting system, the "ColheCana" computational model was adopted as the management platform. The results showed that the mechanized harvesting system using a single-row harvester reached the break-even point in the fourth harvest, while the system using a two-row harvester reached the break-even point in the third harvest.
\end{abstract}

Additional keywords: agribusiness; agricultural mechanization; benchmarking; financial management; planning and management.

\section{Resumo}

O Brasil é o maior produtor mundial de cana-de-açúcar para as usinas produtoras de açúcar, álcool e bioenergia. Elas têm levado em consideração os custos de produção para facilitar o controle financeiro, a fim de auxiliar em tomadas de decisões para rentabilizar a atividade agrícola e deixá-las mais competitivas no mercado. As usinas investem na aquisição de colhedoras e conjuntos mecanizados trator e transbordo para viabilizar o corte, colheita e carregamento interno da cana. Entretanto, a aquisição dessas máquinas agrícolas do sistema de colheita mecanizado, requer alto investimento sobre o fluxo de caixa projetado da usina. Devido a isso, este trabalho teve como objetivo identificar a viabilidade econômica do sistema de colheita mecanizado de cana-de-açúcar para o caixa financeiro da usina. A metodologia empregada considera os custos de implantação e cultivo da lavoura de safras futuras projetadas, a análise de custo pelo Valor Presente Líquido e Taxa Interna de Retorno e os mecanismos referenciadores com o benefício-custo, payback descontado e break even point. Essa metodologia empregada serve para compor o caixa financeiro da usina, sendo que nela foram utilizados dados secundários. Para a geração de dados do sistema de colheita mecanizado de cana-de-açúcar foi adotado, como sendo uma plataforma gerencial, o modelo computacional "ColheCana". Os resultados evidenciaram que o sistema de colheita mecanizado com colhedora de uma linha, alcançou o ponto de equilíbrio na quarta safra, enquanto o sistema com colhedora de duas linhas, alcançou o ponto de equilíbrio na terceira safra.

Palavras-chave adicionais: administração financeira; agronegócio; avaliação comparativa; mecanização agrícola; planejamento e gerenciamento.

\section{Introduction}

In Brazil, the sugarcane cultivated area estimated for the $2020 / 2021$ harvest is of 8.60 million hectares and the forecast of the total production for the harvest is of 665.105 million tons (CONAB, 2020).
According to Santos et al. (2015b) apud CONAB (2008), the Brazilian international leadership of sugarcane production for the manufacturing and sale of sugar and ethyl alcohol occurs due to the organizational capacity of economic agents such as the industry, market, producers, and rural workers. As the sugar and 
alcohol sector has undergone changes that according to Santos et al. (2015b) apud Kohlhepp (2010) occurred due to recent development in the biofuels sector, the country has been going through a comprehensive process of transformation, influencing not only the enormous economic consequences, but also the country's domestic policies.

Sugarcane mills have been taking into account production costs in order to facilitate financial control, assist in the decision-making process to profit from agricultural activity, and to become increasingly stronger and competitive in the market. According to Pereira et al. (2015), production costs basically consist of fixed and variable costs related to the land and the agricultural producer, besides operating costs, which are expenses generated by the producer involving the depreciation of active assets and costs of improvements and labor force. According to Oliveira and Nachiluk (2011), the production costs of a mill comprise the sugarcane cultivation production systems, which require the use of crop protection chemical, correctives, fertilizers, agricultural machinery and implements, and the provision of services for periodic soil preparation, planting, cultural treatments, and harvesting. In addition, according to the authors, agricultural mechanization is one of the biggest bottlenecks in the production costs of a mill. In this context, according to PECEGE (2012), which studied the production costs of sugarcane mills, agricultural mechanization consists of one of the largest shares in costs, with an emphasis on harvesting.

Sugarcane harvesting has been undergoing changes that according to Santos et al. (2015a) were provided by the increase in the cultivated area and production of sugarcane, besides being proven in technical-scientific studies that it is economically viable to harvest the raw material using a fully mechanized method. Furthermore, according to Santos et al. (2014a) and Santos et al. (2015a), sugarcane harvesting has changed from the semi-mechanized to the mechanized system also due to labor and environmental issues inherent to the agroenvironmental protocol signed by leaders of the sugarcane sector, which aims to end the manual burning and cutting of sugarcane fields.

In this context, the sugarcane mills invest in the acquisition of harvesters and tractor-trailer combinations to enable the cutting, harvesting, and internal loading of the raw material. However, the acquisition of mechanized harvesting machines requires a high investment, which even if the investment required was obtained from financing, the mill would be committed to pay through its cash flow projection. Therefore, this study aims to identify the economic viability of a mechanized sugarcane harvesting system for the financial cash of the mill.

\section{Material and methods}

This is a case study that considered bibliographic (secondary) data on the costs of the harvests of sugarcane mills in the state of São Paulo. Secondary data refer to crop and estimated production costs, according to CONAB (2017).

The study considers a mill, called the 'Standard Mill', with its own area of 22,000 hectares for cultivation, harvesting, and production, with six average sugarcane yields. The average yields correspond to future harvests from 2018 to 2023, according to the estimate by NOVACANA (2017).

For the future crop year 2018, a value in United States dollars (US\$) of the price per ton of sugarcane was determined to define the average price for the months from April to September 2017, according to the estimate by the Union of Bioenergy Producers (UDOP, 2017). The price per ton of sugarcane for future harvests from 2019 to 2023 was estimated based on the value per ton of the 2018 harvest using a percentage adopted for the price per ton between a previous harvest and the next harvest. The percentage of the ton value was obtained from the harvests from 2012 to 2017 , according to the estimate by the Union of Bioenergy Producers (UDOP, 2017).

Initially, Elaborated Scenarios 1 and 2 were considered by tabulating secondary data in an electronic spreadsheet and using the computational model "ColheCana", developed by Santos et al. (2014a,2014b; 2015a,2015b). "ColheCana" was prepared considering proposals of operational performance for the sizing of machines and of economic performance for defining the production cost of the mechanized harvesting system. The operational performance was based on the proposals by Mialhe (1974) and Ripoli \& Ripoli (2009) to define the number of harvesters, tractors, and trailers. The economic performance was based on the proposals by ASABE (2011), Banchi et al. (2008b) and Banchi et al. (2008a) to determine the fixed hourly, fuel, repair and maintenance, variable, operational, and production cost of the equipment.

"ColheCana" was used as the management platform to generate data on sizing and production costs for the mechanized sugarcane harvesting system. Only the total cost of the system was tabulated in an electronic spreadsheet. The initial value of the system's equipment are prices estimated by the retailers of the main brands of agricultural machinery in the country.

The tabulation of the secondary data of costs consists of projected future crops from 2018 to 2023. For each crop projection of the 'Standard Mill', owned land and outsourcing of machinery and implements for periodic soil preparation, planting, and cultural treatments were considered according to the estimate by CONAB (2017). The labor force and inputs were considered as belonging to the own mill and were included in the production costs of each projected future crop, according to the CONAB (2017). The labor force used in mechanized harvesting was not considered, as according to Pereira et al. (2015), it is a challenge to be studied. Regarding the harvest, since the first season, the mill acquired equipment of the mechanized 
harvesting system (harvesters and tractor-trailer combinations) with its own capital from the financial cash.

\section{Costs of crop implementation and cultivation for projected future harvests}

For the costs of crop implantation and cultivation, secondary data of the harvests from 2012 to 2017, according to CONAB (2017), were considered for the costs of crop implantation and cultivation.
Secondary data are values (information) that have been published in the state-of-the-art (bibliography). They were adopted to estimate the implantation and cultivation costs of the Standard Mill crop during six projected future harvests, from 2018 to 2023 (Table 1). The projected future harvests from 2018 to 2023 considered the costs of machinery rental and services, labor force, rural administrator, seeds and seedlings, fertilizers, pesticides, and administrative expenses, among others.

Table 1 - Costs of implantation and cultivation of crops for future harvests projected from 2018 to 2023.

\begin{tabular}{lrrrrrr}
\hline- & 2018 & 2019 & 2020 & 2021 & 2022 & 2023 \\
Costs of Crop (US\$ ha-1) & 323 & 426 & 428 & 405 & 468 & 457 \\
\hline
\end{tabular}

\section{Cost analysis methodology}

The purpose of using cost calculations in rural activities is defined by the economic agents involved. The information generated will serve to guide short-term managerial decisions, adjust the long-term business sustainability, calculate the capacity to pay for financing, generate information on the project's viability or at the end of the production process, and identify the profitability of production systems and its causes and consequences. These are the basis for the next planning (Pereira et al., 2015).

In addition, according to Pereira et al. (2015), the financial cash and profit come together in the long term, and the discounted cash flow can be used to calculate the costs of a sugarcane crop. In this study, besides the crop costs, the costs of the mechanized sugarcane harvesting system were calculated using the net present value (NPV) and the internal rate of return (IRR). The IRR and the NPV are mechanisms that work with the notion of the value of money over time in order to evaluate the cash flow of a project, comparing the initial investment with the net results obtained periodically (SENAR, 2016).

In this study, the application of this mechanism for financial evaluation on the projected cash flow of the mill was carried out to determine the annual rate of return expected for the project in the given time horizon (SENAR, 2016). The IRR is calculated by the interest rate that equals the negative initial investment and the expected revenues from the projected cash flow of the mill, according to the idea proposed by Assaf Neto (2010), Gitman (2010) and SENAR (2016), described by Equation 1.

$\mathrm{IRR}=\sum_{t=1}^{n} \frac{\mathrm{CF}_{\mathrm{t}}}{(1+\mathrm{IRR})^{\mathrm{t}}}=0$

Where: IRR is the internal rate of return (\%), $\mathrm{CF}_{\mathrm{t}}$ is the negative initial investment and the revenues expected for the projected cash flow of the mill (United States dollar - US\$), $t$ is the time horizon (months), and 0 is the result.

The NPV indicates whether the project will have a positive or negative result within the given time horizon considering the capital invested in the project (SENAR, 2016). According to Sandroni et al. (1999), the NPV is the present value of future incomes in cash being discounted at an appropriate interest rate and by the difference of the present value of the investment cost. The NPV is calculated by the ratio between the present value of the projected cash flow of the mill and the initial investment capital (discount rate), according to the idea proposed by Assaf Neto (2010), Gitman (2010) and SENAR (2016), described by Equation 2.

$\mathrm{NPV}=\sum_{t=0}^{n} \frac{\mathrm{CF}_{\mathrm{t}}}{(1+\mathrm{i})^{\mathrm{t}}}$

Where: NPV is the net present value (US\$), $\mathrm{CF}_{t}$ is the present value of the projected cash flow of the plant (US\$), $i$ is the initial investment capital (US\$), and $t$ is the time horizon (months).

\section{Reference mechanisms}

The $B / C$ (benefit-cost) ratio informs, within the horizon of analysis of the enterprise, how much each monetary unit of US $\$ 1.00$ would create value also in monetary units, according to the idea proposed by Assaf Neto (2010) and SENAR (2016). The calculation of the $\mathrm{B} / \mathrm{C}$ ratio is defined by the ratio between the project's NPV and the initial investment value, according to the idea proposed by Assaf Neto (2010) and SENAR (2016), described in Equation 3.

$\mathrm{B} / \mathrm{C}=\frac{\mathrm{NPV}}{\mathrm{P} 0}+1$

Where: $B / C$ is the cost-benefit ratio (US\$), NPV is the net present value (US\$), and P0 is the initial investment (US\$).

The discounted payback is a parameter that analyzes the investment used in order to know the time needed to recover this investment (Assaf Neto, 2010; Ramos, 2016). The discounted payback is calculated based on the initial investment (capital contribution) and the NPV of annual revenues, calculated by the time in months necessary for the mill to recover the capital used 
in the acquisition of the mechanized sugarcane harvesting system, according to the idea proposed by SENAR (2016). The calculation is defined by the ratio between the initial investment and the NPV added to the initial investment and as a function of the time horizon, according to the idea proposed by Assaf Neto (2010), Gitman (2010) and SENAR (2016), described in Equation 4.

Discounted payback $=\frac{\mathrm{P} 0}{(\mathrm{NPV}+\mathrm{P} 0) \div \mathrm{t}}+1$

Where: discounted payback is the number of months, $\mathrm{PO}$ is the initial investment (US\$), NPV is the net present value (US\$), and $t$ is the time horizon (months).

The break-even point informs how many units of product (sugarcane production) would have to be produced to pay the costs of the mill. The break-even point indicates when the mill would equal revenue and cost. The calculation is defined by the ratio between the cost per period and the price of the unit of product (ton of sugarcane), according to the idea proposed by
SENAR (2016), described in Equation 5.

Break-even point $=\frac{\text { COPE }}{\text { PUP }}$

Where: Break-even point are the units of sugarcane produced per period ( $t$ year-1), COPE is the cost per period (US\$ year-1), and PUP is the price of the unit of product (ton of sugarcane) (US\$ $\left.\mathrm{t}^{-1}\right)$.

For the definition of the break-even point, the price of a ton of sugarcane, $13.47 \mathrm{US} \$ \mathrm{t}^{-1}$, according to the Union of Bioenergy Producers (UDOP, 2017), was considered as the PUP. In addition, according to Sandroni et al. (1999), the break-even point defines the exact volume of production in which a company does not earn and does not lose money. Above that point the company starts to profit and below that point it suffers losses. Still, according to the authors, the break-even analysis is used to estimate the approximate profits or losses that would occur at the various levels of production (Figure 1).

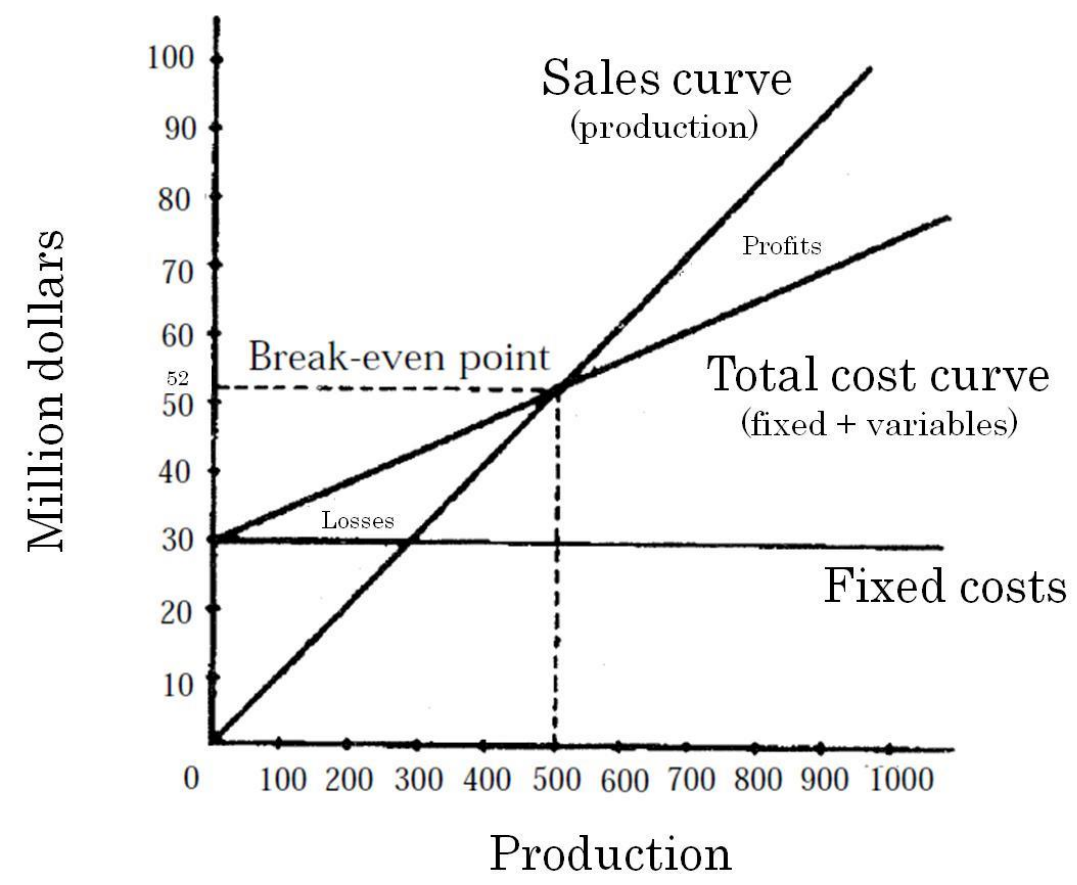

Figure 1 - Break even point demo (Adapted from Sandroni et al.,1999).

\section{Results and discussion}

For the results of the Standard Mill, Elaborated Scenarios 1 and 2 were considered. Elaborated Scenario 1 considered the mechanized sugarcane harvesting system with a single-row harvester. Elaborated Scenario 2 considered the mechanized sugarcane harvesting system with a two-row harvester.

\section{Elaborated scenario 1}

In Table 2, the data of agronomic and agricultural variables of future crops projected for Scenario 1 are presented. In this scenario, the number of equipment necessary was 11 harvesters, 22 tractors, and 44 trailers.

The production cost of the harvester was US\$ $0.98 \mathrm{t}^{-1}$ and the production cost of the tractor-trailer combination was US $\$ 0.70 \mathrm{t}^{-1}$.

Figure 2 shows the layout of the data generated by the computational model "ColheCana" for Scenario 1. 
Table 2 - Input and output data of agronomic and agricultural variables of future harvests projected in scenario 1.

\begin{tabular}{|c|c|c|c|c|c|c|}
\hline Agronomic & 2018 & 2019 & 2020 & 2021 & 2022 & 2023 \\
\hline Area (ha) & 22,000 & 22,000 & 22,000 & 22,000 & 22,000 & 22,000 \\
\hline Crop Spacing (m) & 1.5 & 1.5 & 1.5 & 1.5 & 1.5 & 1.5 \\
\hline Yield $\left(\mathrm{t} \mathrm{ha}{ }^{-1}\right)$ & 77 & 78 & 79 & 80 & 81 & 82 \\
\hline Production (t) & $1,694,000$ & $1,716,000$ & $1,738,000$ & $1,760,000$ & $1,782,000$ & $1,804,000$ \\
\hline $\begin{array}{l}\text { Average Price of the Ton of Sugarcane } \\
\left(\text { US } \$ t^{-1}\right)\end{array}$ & 14.44 & 13.83 & 13.25 & 13.87 & 14.88 & 18.90 \\
\hline Agricultural & 2018 & 2019 & 2020 & 2021 & 2022 & 2023 \\
\hline Harvester Initial Value (US\$) & \multicolumn{6}{|c|}{193,424} \\
\hline Tractor Initial Value (US\$) & \multicolumn{6}{|c|}{63,056} \\
\hline Sugarcane Trailer Initial Value (US\$) & \multicolumn{6}{|c|}{17,408} \\
\hline Number of Harvesters & 11 & 11 & 11 & 11 & 11 & 11 \\
\hline Number of Tractors & 22 & 22 & 22 & 22 & 22 & 22 \\
\hline Number of Trailers & 44 & 44 & 44 & 44 & 44 & 44 \\
\hline Harvester Production Cost (US $\left.\$ t^{-1}\right)$ & 0.98 & 0.98 & 0.98 & 0.98 & 0.98 & 0.98 \\
\hline Tractor-Trailer Production Cost $\left(\mathrm{US} \$ \mathrm{t}^{-1}\right)$ & 0.70 & 0.70 & 0.70 & 0.70 & 0.70 & 0.70 \\
\hline $\begin{array}{l}\text { Total Investment Value of the } \\
\text { Mechanized Harvesting System (US\$) }\end{array}$ & \multicolumn{6}{|c|}{$4,280,851$} \\
\hline $\begin{array}{l}\text { Total Cost of the Mechanized Harvesting } \\
\text { System (US\$) }\end{array}$ & $2,847,362$ & $2,884,340$ & $2,921,319$ & $2,958,298$ & $2,995,277$ & $3,032,255$ \\
\hline
\end{tabular}

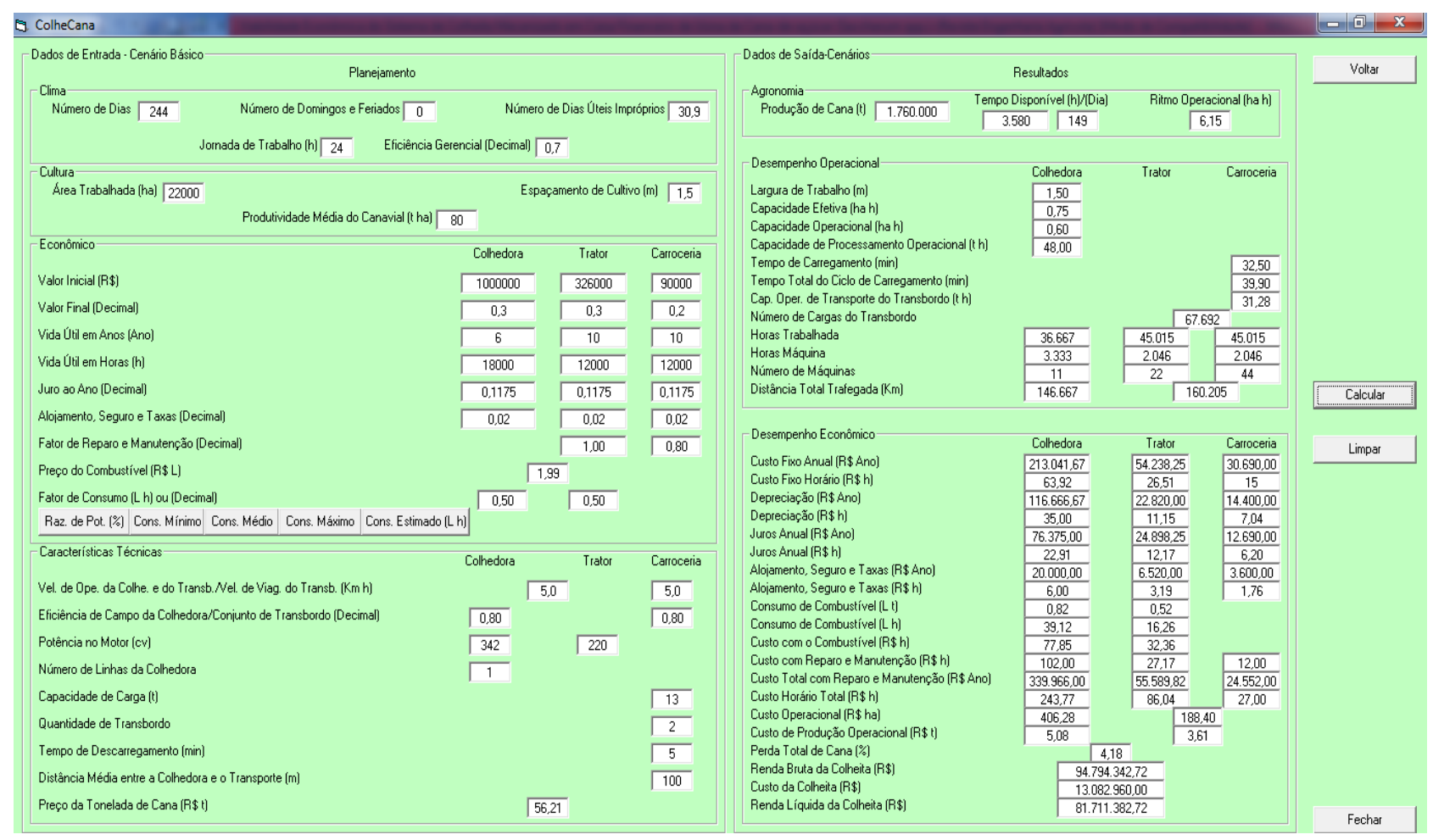

Figure 2 - Layout of the data generated by "ColheCana" in scenario 1.

Table 3 shows the cash flow of the mill with the inflows and outflows referring to the crop for Scenario 1. The inflows refer to the total revenue of the mill per harvest projection and the capital invested in the acquisition of machines for the mechanized harvesting system. The capital investment is the value for the acquisition of the machinery, which in this scenario resulted in US\$4,280,851. 
Table 3 - Cash flow from the Standard Mill for scenario 1.

\begin{tabular}{|c|c|c|c|c|c|c|}
\hline Income/Expenses & 2018 & 2019 & 2020 & 2021 & 2022 & 2023 \\
\hline Inflows & & & & & & \\
\hline Sugarcane (US\$) & $24,463,610$ & $23,735,547$ & $23,025,368$ & $24,410,387$ & $26,524,693$ & $34,099,556$ \\
\hline Capital Investment (US\$) & $4,280,851$ & & & - & & \\
\hline Total Inflows (US\$) & $28,744,461$ & $23,735,547$ & $23,025,368$ & $24,410,387$ & $26,524,693$ & $34,099,556$ \\
\hline Outflows & & & & & & \\
\hline Investments (US\$) & \multicolumn{6}{|c|}{$4,280,851$} \\
\hline $\begin{array}{l}\text { Cost of the Mechanized } \\
\text { Harvesting System (US\$) }\end{array}$ & $2,847,362$ & $2,884,340$ & $2,921,319$ & $2,958,298$ & $2,995,277$ & $3,032,255$ \\
\hline Crop Cost (US\$) & $7,114,867$ & $9,369,338$ & $9,411,752$ & $8,918,605$ & $10,295,509$ & $10,327,583$ \\
\hline $\begin{array}{l}\text { Total Outflows (Total Cost) } \\
\text { (US\$) }\end{array}$ & $14,243,079$ & $12,253,678$ & $12,333,072$ & $11,876,903$ & $13,290,785$ & $13,359,838$ \\
\hline Operating Balance (US\$) & $14,501,382$ & $11,481,869$ & $10,692,296$ & $12,533,484$ & $13,233,908$ & $20,739,717$ \\
\hline$\overline{\text { Profit (Mill Revenue) (US\$) }}$ & $14,501,382$ & $11,481,869$ & $10,692,296$ & $12,533,484$ & $13,233,908$ & $20,739,717$ \\
\hline
\end{tabular}

The outflows refer to the investment in the acquisition of machines for the mechanized harvesting system, system and crop cost, total outflows, and operating balance per projected future crop. Following the inflows and outflows of revenue and expenses, there is the future crop revenue projection of the mill for this scenario.

Table 4 presents the analysis for the six-year horizon for Scenario 1.

According to the cost analysis methodology, the maximum interest rate informed by the IRR that the investment would bear was $3.22 \%$. The NPV indicated that the investment has a positive result of US\$ $45,904,079$. The $B / C$ ratio informed that for every US $\$$ 1.00 , US $\$ 2.27$ was created. According to the discounted payback, the return on investment would occur in six months. The break-even point indicated that the revenues and expenses of the mill are equal when reaching 685,939 $\mathrm{t}_{\text {year }}{ }^{-1}$.Figure 3 shows the costs and revenues of the mill as a function of the projected future harvests of Scenario 1.

Table 4 - Analysis for the six-year horizon for Scenario 1.

\begin{tabular}{c|c}
\hline IRR $^{1}$ & $3.22 \%$ \\
$\mathrm{NPV}^{2}$ & US $\$ 45,904,079$ \\
$\mathrm{~B}^{3}$ & US $\$ 1.00:$ US $\$ 2.27$ \\
Discounted payback & 6 months \\
Break-even point & 685,939 t year $^{-1}$ \\
\hline
\end{tabular}

For the Elaborated Scenario 1 (Figure 3), the accumulated cost of the mechanized harvesting system presented linear growth over the harvests, since the methodology adopted by "ColheCana" considers fixed values of the machinery capital, which are maintained over the usable life of the equipment. The accumulated costs of the crop and total costs and the accumulated revenue of the mill presented polynomial growth throughout the harvests.

In addition, in the first harvest, the total cost would be higher than the mill revenue from the 2021 harvest (4th harvest/year), when the intersection between total costs and revenue occurs, being called the " $Z$ " break-even point. The break-even point is the indication that from this harvest (2021) onwards the mechanized sugarcane harvesting system would become viable for the mill. Therefore, this shows that the harvests prior to the occurrence of the break-even point comprised the period when the mill was recovering the capital invested for the acquisition of the mechanized harvesting system.

\footnotetext{
${ }^{1}$ IRR - Internal Rate of Return;

${ }^{2}$ NPV - Net Present Value;

${ }^{3} \mathrm{~B} / \mathrm{C}$ - Benefit-Cost Ratio.
} 


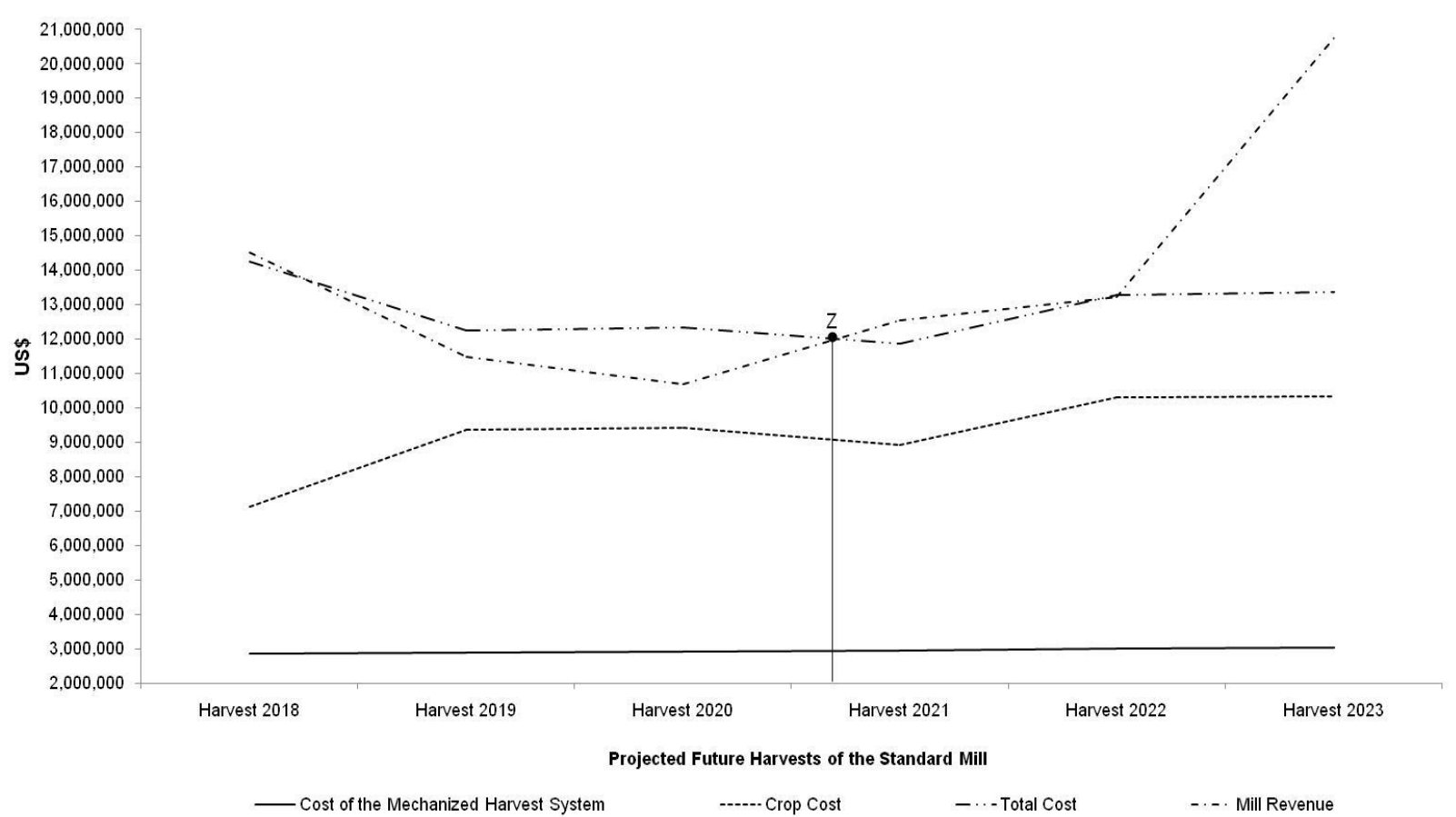

Figure 3 - Usina Padrão's costs and revenue due to the projected future harvests of scenario 1.

\section{Elaborated scenario 2}

In Table 5, the data of agronomic and agricultural variables of future crops projected for
Scenario 2 are shown. For this scenario, the number of machines resulted in 7 harvesters, 14 tractors, and 28 trailers.

Table 5 - Input and output data for the agronomic and agricultural variables of future harvests projected in Scenario 2.

\begin{tabular}{|c|c|c|c|c|c|c|}
\hline Agronomic & 2018 & 2019 & 2020 & 2021 & 2022 & 2023 \\
\hline$\overline{\text { Area (ha) }}$ & 22,000 & 22,000 & 22,000 & 22,000 & 22,000 & 22,000 \\
\hline Crop Spacing (m) & 2.5 & 2.5 & 2.5 & 2.5 & 2.5 & 2.5 \\
\hline Yield $\left(\mathrm{t} \mathrm{ha}^{-1}\right)$ & 77 & 78 & 79 & 80 & 81 & 82 \\
\hline Production (t) & $1,694,000$ & $1,716,000$ & $1,738,000$ & $1,760,000$ & $1,782,000$ & $1,804,000$ \\
\hline $\begin{array}{l}\text { Average Price of the Ton of } \\
\text { Sugarcane }\left(U S \$ t^{-1}\right)\end{array}$ & 14.44 & 13.83 & 68.49 & 13.87 & 14.88 & 18.90 \\
\hline Agricultural & 2018 & 2019 & 2020 & 2021 & 2022 & 2023 \\
\hline Harvester Initial Value (US\$) & \multicolumn{6}{|c|}{$\begin{array}{l}264,990 \\
63056\end{array}$} \\
\hline Tractor Initial Value (US\$) & & & & & & \\
\hline $\begin{array}{l}\text { Sugarcane Trailer Initial Value } \\
\text { (US\$) }\end{array}$ & \multicolumn{6}{|c|}{17,408} \\
\hline Number of Harvesters & 7 & 7 & 7 & 7 & 7 & 7 \\
\hline Number of Tractors & 14 & 14 & 14 & 14 & 14 & 14 \\
\hline Number of Trailers & 28 & 28 & 28 & 28 & 28 & 28 \\
\hline $\begin{array}{l}\text { Harvester Production Cost (US } \$ \mathrm{t}^{-} \\
\text {1) }\end{array}$ & 0.75 & 0.75 & 0.75 & 0.75 & 0.75 & 0.75 \\
\hline $\begin{array}{l}\text { Tractor-Trailer Production Cost } \\
\left(\text { US } \$ t^{-1}\right)\end{array}$ & 0.46 & 0.46 & 0.46 & 0.46 & 0.46 & 0.46 \\
\hline $\begin{array}{l}\text { Total Investment Value of the } \\
\text { Mechanized Harvesting System } \\
\text { (US\$) }\end{array}$ & \multicolumn{6}{|c|}{$3,225,145$} \\
\hline $\begin{array}{l}\text { Total Cost of the Mechanized } \\
\text { Harvesting System (US\$) }\end{array}$ & $2,053,393$ & $2,080,060$ & $2,106,728$ & $2,133,396$ & $2,160,063$ & $2,186,731$ \\
\hline
\end{tabular}


The production cost of the harvester was US\$ $0.75 \mathrm{t}^{-1}$ and the production cost of the tractor-trailer combination was US $\$ 0.46 \mathrm{t}^{-1}$.
Figure 4 shows the layout of the data generated by the computational model "ColheCana" for Scenario 2.

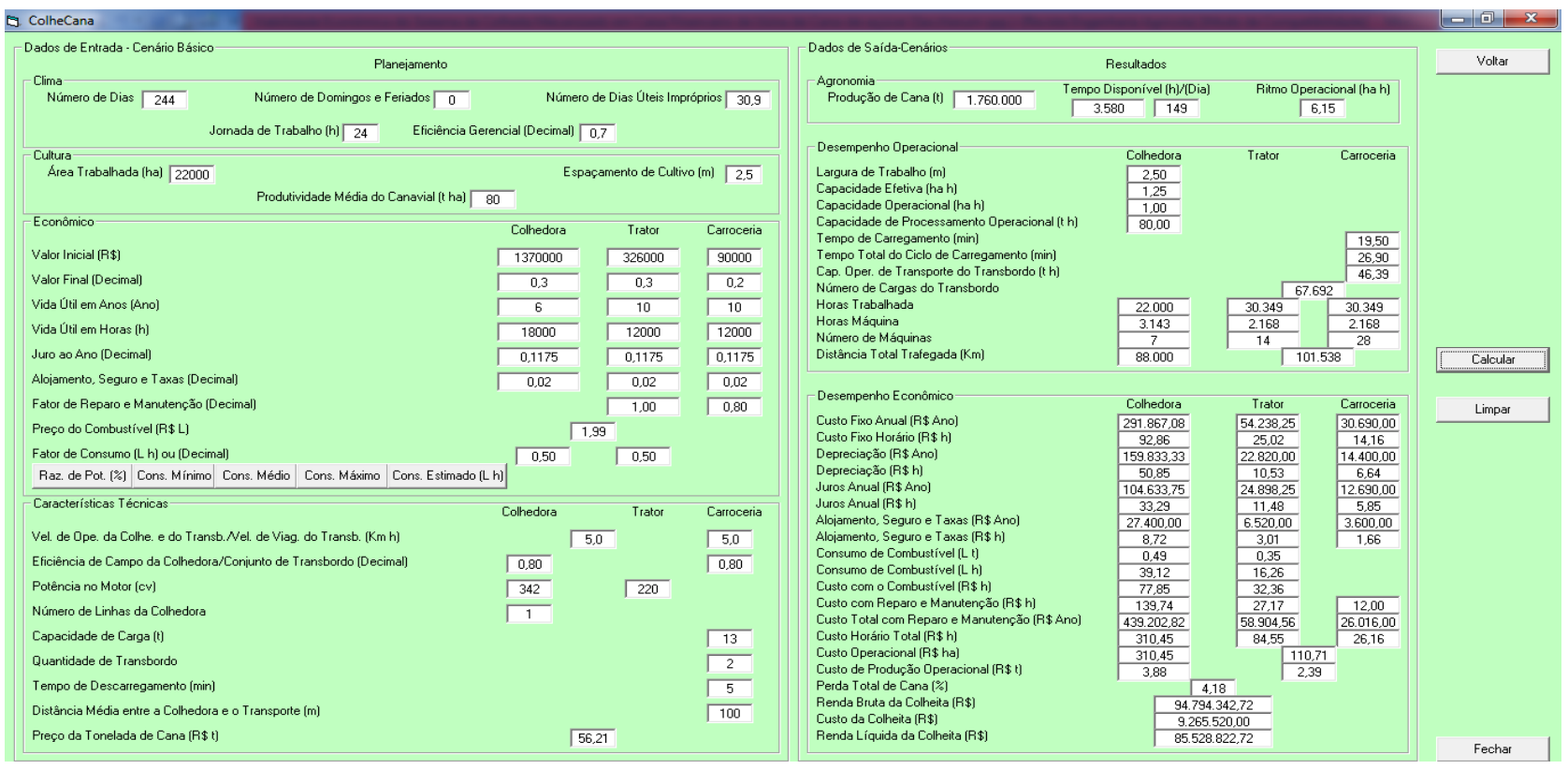

Figure 4 - Layout of the data generated by "ColheCana” in scenario 2.

In this scenario, there was a reduction both in the cost of production of equipment as in the number of harvesters, tractors, and trailers compared to the previous scenario. The reduction occurred as the tworow harvester was considered, which has greater effective working width due to the double alternating crop rows, providing greater operational field and operational processing capacity and reducing the working hours compared to a single-row harvester, which harvests in single-crop rows. Thus, according to the methodology considered to determine the number of machines, the cost of production of equipment and the operational performance of the two-row harvester is superior to that of a single-row harvester, resulting in the reduction of the production cost of the machines and of the number of harvesters, tractors, and trailers by $36.36 \%$. This is an analysis of strategic capital allocation for the acquisition of machinery, which is a useful tool in the decision-making of agricultural managers of the mill.

Table 6 shows the mill cash flow with the inflows and outflows referring to the crop for Scenario 2. The inflows refer to the total revenue of the mill per harvest projection and the capital invested in the acquisition of machines of the mechanized harvesting system. The capital investment is the value for the acquisition of the machinery, which in this scenario resulted in US\$ $3,225,145$.

Table 6 - Cash flow from the Standard Mill for Scenario 2.

\begin{tabular}{|c|c|c|c|c|c|c|}
\hline Income/Expenses & 2018 & 2019 & 2020 & 2021 & 2022 & 2023 \\
\hline Inflows & \multirow{3}{*}{$\begin{array}{r}24,463,610 \\
3,225,145\end{array}$} & \multirow{3}{*}{$23,735,547$} & \multirow{3}{*}{$23,025,368$} & \multirow{3}{*}{$24,410,387$} & \multirow{3}{*}{$26,524,693$} & \multirow{3}{*}{$34,099,556$} \\
\hline Sugarcane (US\$) & & & & & & \\
\hline Capital Investment (US\$) & & & & & & \\
\hline Total Inflows (US\$) & \multirow[t]{3}{*}{$27,688,755$} & \multirow[t]{3}{*}{$23,735,547$} & \multirow[t]{2}{*}{$23,025,368$} & \multirow[t]{2}{*}{$24,410,387$} & \multirow[t]{3}{*}{$26,524,693$} & \multirow[t]{3}{*}{$34,099,556$} \\
\hline Outflows & & & & & & \\
\hline Investments (US\$) & & & \multicolumn{2}{|c|}{$3,225,145$} & & \\
\hline $\begin{array}{l}\text { Cost of the Mechanized } \\
\text { Harvesting System (US\$) }\end{array}$ & $2,053,393$ & $2,080,061$ & $2,106,728$ & $2,133,396$ & $2,160,063$ & $2,186,731$ \\
\hline Crop Cost (US\$) & $7,114,867$ & $9,369,338$ & $9,411,752$ & $8,918,605$ & $10,295,509$ & $10,065,115$ \\
\hline $\begin{array}{l}\text { Total Outflows (Total Cost) } \\
\text { (US\$) }\end{array}$ & $12,393,405$ & $11,449,399$ & ,481 & 2,001 & $12,455,572$ & $12,251,846$ \\
\hline Operating Balance (US\$) & $15,295,350$ & $12,286,149$ & $11,506,887$ & $13,358,386$ & $14,069,121$ & $21,847,710$ \\
\hline Profit (Mill Revenue) (US\$) & $15,295,350$ & $12,286,149$ & $11,506,887$ & $13,358,386$ & $14,069,121$ & $21,847,710$ \\
\hline
\end{tabular}


The outflows refer to the investment in the acquisition of machines of the mechanized harvesting system, system and crop cost, total outflows, and operating balance per projected future crop. Following the inflows and outflows of revenue and expenses, there is the future crop revenue projection of the mill for this scenario.

Table 7 shows the analysis for the six-year horizon for Scenario 2.

According to the cost analysis methodology, the maximum interest rate informed by the IRR that the investment would bear was $4.57 \%$. The IRR was higher as the project did not consider the land immobilized capital, the agro-industrial plant of the mill, the sugarcane production process, agricultural equipment, logistics, and irrigation, among others. However, if they were considered, a larger capital would certainly be immobilized and it would take a few decades for obtaining return on invested capital.

The NPV indicated that the investment has a positive result of US $\$ 49,962,194$. The $B / C$ ratio informed that for every US\$1.00, US\$ 3.19 was created. According to the discounted payback, the return on investment would occur in four months. The break-even point indicated that the revenues and expenses of the mill are equal when reaching $682,691 \mathrm{t}$ year $^{-1}$.

Figure 5 shows the costs and revenue of the plant as a function of the projected future harvests of scenario 2.

According to Elaborated Scenario 2 (Figure 5), in the first two years of harvests, the mill revenue would be higher than the total cost until the 2020 harvest (3rd harvest/year), when the intersection between total costs and revenue would occur, being called the " $Z$ " breakeven point. The mill revenue returns to be higher than the total cost from this point until the last harvest. The break-even point is the indication that from this harvest (2020) onwards the mechanized sugarcane harvesting system would become viable for the mill. Therefore, this shows that the harvests prior to the occurrence of the break-even point comprised the period when the mill was recovering the capital invested for the acquisition of the machines of the mechanized harvesting system.

Therefore, the mechanized harvesting system using a two-row, chop harvester in the Elaborated Scenario 2 (Figure 5) provided economic viability for the mill in a previous harvest compared to the mechanized harvesting system with a single-row, chop harvester in the Elaborated Scenario 1 (Figure 3).

Table 7 - Analysis for the six-year horizon for Scenario 2.

\begin{tabular}{c|c}
\hline $\mathrm{IRR}^{4}$ & $4.57 \%$ \\
$\mathrm{NPV}^{5}$ & US $\$ 49,962,194$ \\
$\mathrm{~B}^{6}$ & US $\$ 1.00:$ US $\$ 3.19$ \\
Discounted payback & 4 months \\
Break-even point & 682,691 t year $^{-1}$ \\
\hline
\end{tabular}

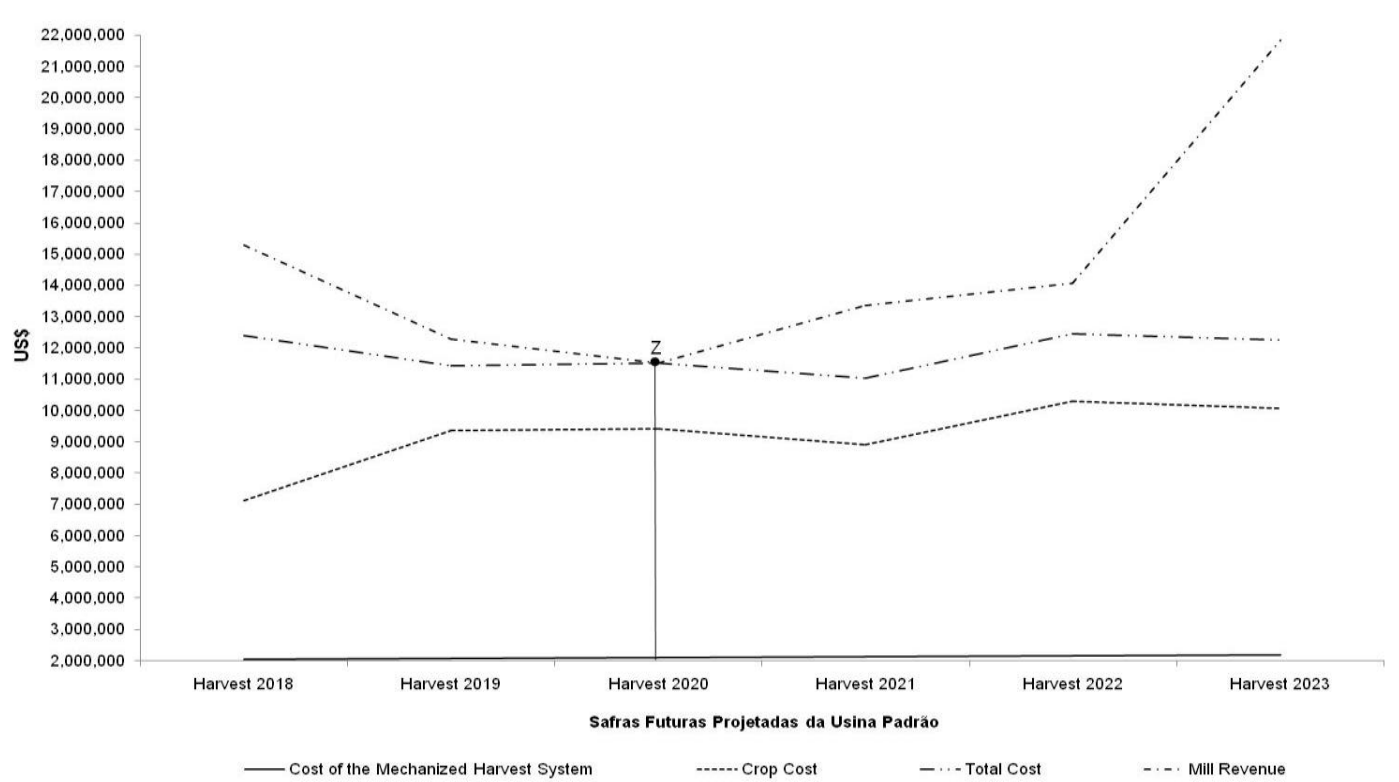

Figure 5 - Usina Padrão's costs and revenue due to the projected future harvests of scenario 2.

\footnotetext{
${ }^{4}$ IRR - Internal Rate of Return;

${ }^{5}$ NPV - Net Present Value;

${ }^{6} \mathrm{~B} / \mathrm{C}$ - Benefit-Cost Ratio.
} 


\section{Conclusions}

The mechanized harvesting system is viable for the financial cash of the mill from the break-even point onwards.

Mechanized harvesting with a two-row, chop harvester presented greater economic viability for the financial cash of the mill compared to the single-row harvester.

\section{References}

ASABE - American Society of Agricultural and Biological Engineers (2011) Agricultural machinery management data ASAE D497.7. In: 8. ASABE Standards. p.1-

Assaf Neto A (2010) Finanças corporativas e valor. (5 ed). Atlas. 726p.

Banchi AD, Lopes JR, Zago CA (2008a) Estudo dos custos com reparo e manutenção em colhedoras de cana-de-açúcar parte II. Revista Agrimotor (31):8-10.

Banchi AD, Lopes JR, Zago CA (2008b) Uso anual e consumo de combustível em frotas agrícolas. Revista Agrimotor (39):8-10 .

CONAB - Companhia Nacional de Abastecimento (2020) Acompanhamento da safra brasileira: cana-deaçúcar, terceiro levantamento. Brasília, v. 7, n. 3. Online. Disponível em <https://www.conab.gov.br/component/k2/item/downlo ad/34870_e1c52a336b53ca05c29824831da3c9e9>. Acesso em 03 fev. 2021.

CONAB - Companhia Nacional de Abastecimento (2017) Custos de produção - cultura semi-perene: canade-açúcar - SP - 2011 a 2017. Brasília, Online. Disponível em $<$ http://www.conab.gov.br/conteudos.php?a=1558\&t=2 >. Acesso em 04 nov. 2017.

CONAB - Companhia Nacional de Abastecimento (2008) Perfil do setor do açúcar e do álcool no brasil. Brasília, Online. p. 7-74. Disponível em <http://www.agricultura.gov.br/arq_editor/file/Desenvol vimento_Sustentavel/Agroenergia/estatisticas/produca o/Perfil_Setor_Acucar_Alcool_2007_08_PDF.pdf>. Acesso em 23 set. 2014.

Gitman LJ (2010) Princípios de administração financeira. (12 $\left.2^{\mathrm{a}} \mathrm{ed}\right)$. Pearson Prentice Hall. 775p.

Kohlhepp G (2010) Análise da situação da produção de etanol e biodiesel no Brasil. Estudos Avançados 24(68):223-253. doi: http://dx.doi.org/10.1590/S010340142010000100017.
Mialhe LG (1974) Manual de mecanização agrícola. Agronômica Ceres. 301p.

NOVACANA (2017) As projeções de produção de cana, açúcar e etanol para a safra 2023/24 da FIESP/MB Agro. Curitiba, Online. Disponível em $<$ https://www.novacana.com/estudos/projecoesproducao-cana-acucar-etanol-safra-2023-2024-fiespmb-agro/>. Acesso em 09 nov. 2017.

Oliveira MDM, Nachiluk K (2011) Custo de produção de cana-de-açúcar nos diferentes sistemas de produção nas regiões do Estado de São Paulo. Informações Econômicas 41(1):5-33.

PECEGE - Programa de Educação Continuada em Economia e Gestão de Empresas (2012) Custos de produção de cana-de-açúcar, açúcar e etanol no Brasil: acompanhamento da safra 2011/2012 - Centro-Sul. Piracicaba, $1^{\text {a }}$ ed., p.57. Online. Disponível em $<$ http://canaldoprodutor.com.br/sites/default/files/relator io_Custos_Prod_Cana_2011_12.pdf>. Acesso em 26 set. 2017.

Pereira GGS, Albrecht AJP, Fausto DA, Migliavacca RA (2015) Custo de produção de cana-de-açúcar no Estado do Mato Grosso do Sul. Revista iPecege 1(1):81-102. doi: https://doi.org/10.22167/r.ipecege.2015.1.81.

Ramos IS (2016) Administração financeira. Fael, 175p.

Ripoli TCC, Ripoli MLC (2009) Biomassa de cana-deaçúcar: colheita, energia e ambiente. Edição dos Autores. 333p.

Sandroni P, Biava A, Lacerda AC, Maia CDM, Galvani $\mathrm{C}$, Cavalieri $\mathrm{CH}$, Bueno CW, Sacardo $\mathrm{C}$, Mello $\mathrm{CHP}$, Vignoli F, Masiero G, Froelich GM, Santos JP, Maia JBZ, Camargo JM, Dowbor L, Pedrosa MF, Audi MT, Moraes OJ, Gonçalves RA, Bonanno R, Sawaya R, Tarso e Sousa S, Malvezzi S, Miyazaki S, Carmona AM, Borges CM, Silva GB, Okomura JL, Nava L, Sandroni LAM, Viana MR, Marçal MD (1999) Novíssimo dicionário de economia. Best Seller. 649p. Disponível em $<$ http://sinus.org.br/2014/wpcontent/uploads/2013/11/FMI.BMNov\%C3\%ADssimoDicion\%C3\%A1rio-de-Economia.pdf>. Acesso em 22 maio 2019.

Santos NB, Cavalcante DS, Fernandes HC, Gadanha Júnior CD (2015a) Tempo é dinheiro. Cultivar Máquinas (149):36-38.

Santos NB dos, Fernandes HC, Gadanha Júnior CD (2015b) Economic impact of sugarcane (Saccharum spp.) loss in mechanical harvesting. Científica 43(1):1621. doi: http://dx.doi.org/10.15361/19845529.2015v43n1p16-21. 
Santos NB, Cavalcante DS, Fernandes HC, Gadanha Júnior CD (2014a) Simulação da eficiência de campo da colheita mecanizada de cana-de-açúcar (Saccharum spp.). Revista Energia na Agricultura 29(1):09-13. doi: http://dx.doi.org/10.17224/EnergAgric.2014v29n1p0913.

Santos NB, Silva RP, Gadanha Junior CD (2014b) Economic analysis for sizing of sugarcane (Saccharum spp.) mechanized harvesting. Engenharia Agrícola 34(5):945-954. doi: http://dx.doi.org/10.1590/S010069162014000500013.
SENAR - Serviço Nacional de Aprendizagem Rural (2016) Curso técnico em agronegócio: finanças aplicadas ao agronegócio. SENAR. 174p.

UDOP - União dos Produtores de Bioenergia (2017) Valores de ATR e preço da tonelada de cana-de-açúcar - Consecana do Estado de São Paulo. Araçatuba, Online. Disponível em <http://www.udop.com.br/cana/tabela_consecana_sao paulo.pdf>. Acesso em 13 nov. 2017. 